\begin{tabular}{|l|l|l|l|l|l|}
\hline J. Tek. Ling & Vol. 12 & No. 1 & Hal. 55 - 65 & Jakarta, Januari 2011 & ISSN 1441-318X \\
\hline
\end{tabular}

\title{
PROSPEK TEKNOLOGI REMEDIASI LAHAN KRITIS DENGAN ASAM HUMAT (Humic Acid)
}

\author{
Untung Suwahyono \\ Pusat Teknologi Bioindustri. BPP Teknologi Gd.II Lantai 15. \\ JI. M,H Thamrin No.8 Jakarta. 10340 \\ untung_suwahyono@yahoo.co.id
}

\begin{abstract}
ABSTRAK
The green revolution in the 19th century, has met expectations in an effort to increase the productivity of food supply, in the world at least in Indonesia. In the course of time the green revolution movement has given the systemic impact not only on the degradation of ecosystems, but also the productivity of land, especially paddy fields due to the use of agrochemicals that have been over threshold. The impact on soil in Indonesia become ill, there is a change of soil structure, become poorer and finally lost as the land carrying capacity of production. Systemic Degradation covering 18000 ha of wetland, contamination levels of heavy metals such as $\mathrm{Hg}, \mathrm{Fe}, \mathrm{Cd}, \mathrm{Cu}$ has been on conditions that endanger human health also pesticide has an impact resistance to pests.

Recovery efforts of agricultural land, will take time, and cost is not cheap. Various studies have been done, to remediation land by using acid-humic substances, and gives results quite encouraging, because it's quite effective, efficient and inexpensive, compared with conventional methods is to provide an organic material such as kompost.
\end{abstract}

Keywords: Humic-acide, remediation, agricultural field.

\section{PENDAHULUAN}

\subsection{Degradasi Sitemik Lahan Sawah}

Revolusi hijau pada abad ke-19 awalnya di Eropa, dan pengaruh revolusi ini menjalar ke Amerika utara sekitar tahun 1850-1950, telah berhasil merubah pola pertanian dunia. Dampak revolusi ini ditengarai dengan penggunaan bahan agrokimia seperti pupuk an-organik dan pestisida kimia secara intensif untuk meningkatkan produksi usaha pertanian terutama pangan. Konon hasil dari revolusi hijau ini meningkatkan produksi komoditas pangan yang cukup bermakna di kawasan Eropa. (sudah menjadi pernyataan publik, tidak perlu sumber refrensi)
Di Indonesia teknologi revolusi hijau digulirkan sejak tahun 1960, dan menunjukan dampak positif terhadap kenaikan produksi padi nasional. Produksi padi nasional yang tadinya hanya 18 juta ton pada tahun 1970 meningkat menjadi 54 juta ton pada tahun 2004 , atau kenaikan produktivitas lahan yang tadinya 2,25 T/ha menjadi 4,58T/ha ${ }^{13}$.

Bergulirnya waktu penerapan teknologi revolusi hijau, walapun pada awalnya berdampak positif terhadap kenaikan produksi pangan umumnya dan padi khususnya, dalam perjalanan waktu muncul dampak negatif, yang antara lain ditengarai oleh kecenderungan meningkatnya pasokan 
energi dari luar yang tinggi terutama untuk pupuk dan pestisida kimia. Intensifikasi teknologi revolusi hijau penggunaan pupuk meningkat hampir 6 kali ganda, pada tahun 1970 rata-rata 635 ribu ton, menjadi 4,42 juta ton pada tahun 2003. Menurut Irsal $\mathrm{dkk}^{13)}$, penggunaan pupuk oleh petani umumnya berlebihan, kisaran penggunaan pupuk urea(N) pada kisaran $100-800 \mathrm{~kg} /$ ha, pupuk fosfat $(P) 0-300 \mathrm{~kg} / \mathrm{ha}$, dan kalium (K) $0-250 \mathrm{~kg} / \mathrm{ha}$. Demikian pula terjadi kecenderungan peningkatan pengunaan pestisida kimia menurut catatan pada tahun 1978 mencapai 5.234 ton, dan pada tahun 1986 setelah teknologi revolusi hijau digulirkan mencapai 18.000 ton $^{13)}$.

Fenomena kejenuhan tanah/lahan akan produk agrokimia antara lain meningkatnya residu pupuk, dan berdampak lebih jauh terjadinya cemaran logam berat seperti timbal $(\mathrm{Pb})$ dan kadmium(Cd). Penelitian yang dilakukan di daerah Pantura Jawa oleh Ardiwinata, dkk ${ }^{1)}$, dan Kasno, dkk ${ }^{14)}$, menunjukkan bahwa, 21-40\% lahan sawah sudah tercemari oleh kedua jenis logam tersebut, ditemukan pula bahwa, 4-7\% dari lahan tersebut dapat dikatagorikan terkontaminasi berat ( $>1,0$ dan $>0,24 \mathrm{ppm})$. Disamping pencemaran pada lahan karena residu, pupuk( $\mathrm{N})$ mengakibatkan pencemaran senyawa nitrat $\left(\mathrm{NO}_{3}\right)$ pada sumber daya air (irigasi,air tanah). Hasil penelitian bahwa $85 \%$ air irigási sawah di Jawa mengandung 5,40 ppm, sedangkan batas ambang tertinggi diperbolehkan 4.50 ppm $^{13)}$.

Menilik pada perkembangan di atas yaitu dampak dari teknologi revolusi hijau, disadari atau tidak telah mengakibatkan permasalahan baru di sector pertanian. Hal ini kiranya menjadikan perhatian yang serius bagi para pihak dalam upaya meningkatkan ketahanan pangan, produktivitas dan kesehatan.

\subsection{Pembenahan Tanah/Lahan.}

Pembenahan tanah atau terminologi umum dengan sebutan remediasi atau rekondisi tanah yang mengalami degradasi kesuburan, atau terkena cemaran sehingga menjadi kurang produktif atau tidak subur. Degradasi tanah dan lahan terjadi tidak saja karena cemaran bahan agrokimia, tetapi dapat disebabkan juga karena erosi, dan pengelolaan lahan yang tidak tepat sehingga mengakibatkan menurunnya daya dukung sifat físika, kimia dan biologi tanah. Apabila tanah kandungan humusnya semakin berkurang, maka lambat laun tanah akan menjadi keras, kompak dan bergumpal seperti tanah lempung, sehingga menjadi kurang produktif. ${ }^{34)}$. Dilaporkan, oleh Sugito, $\mathrm{dkk}^{32)}$ bahwa, sekitar 60 persen areal sawah di Jawa kadungan bahan organiknya kurang dari 1\%. Lahan-lahan sawah di Jawa untuk budidaya padi terus menerus terjadi kondisi kritis terjadi defisiensi unsur hara seperti $\mathrm{Zn}$ dan $\mathrm{Cu}$, sementara itu bahwa ekosistem sawah menurut Handayanto ${ }^{11)}$, akan berkelanjutan jika kandungan bahan organik lebih dari $2 \%$.Ciri umum tanah atau lahan kritis atau tingkat produktivitasnya rendah ditandai dengan tingginya tingkat kemasaman tanah, kekahatan hara $\mathrm{P}, \mathrm{K}, \mathrm{C}$ dan $\mathrm{Mg}$, rendahnya kapasitas tukar ion (KTK), kejenuhan basa dan kandungan bahan organik rendah" ${ }^{19)}$, (Mahfudz.,2001).

Pembenahan lahan kritis dan suboptimal dapat dilakukan dengan berbagai metoda yaitu, reboisasi, penghijauan, konservasi dan penambahan bahan organik. Komponen organik seperti asam humat dan asam fulvat dalam hal ini berperan sebagai sementasi pertikel lempung dengan membentuk komplek lempunglogam-humus ${ }^{34)}$, (Stevenson,1982). Caracara pembenahan yang akan diterapkan ini tergantung pada kondisi geografis lahan. Untuk lahan geografis pegunungan pengkayaan sumber bahan organik mungkin akan lebih tepat dengan cara reboisasi, dan penghijauan. Namun akan berbeda untuk lahan-lahan usaha pertanian, karena sifat geografisnya spesifik.

Cara-cara konvesional yang sering kali dilakukan, sifatnya tindak kearifan lokal 
masyarakat petani pada tempo dulu yaitu mengembalikan seresah bahan organik sisa panen kelahan sawah. Ini adalah bentuk apresiasi petani yang berwawasan kesimbangan alam, namun saat ini tampaknya pola ini telah berubah, karena produk limbah hasil panen sudah menjadi komoditi ekonomi. Hanya di beberapa tempat saja pola tindak seperti diatas masih dapat ditemui. Hal ini tentunya memunculkan masalah tersendiri hilangnya upaya mandiri petani dan kearifan lokal untuk memuliakan lahan produksinya.

Beberapa contoh penelitian akademis untuk mengangkat kembali kearifan lokal pemuliaan lahan produksi. Penelitian yang dilakukan oleh Toha dan Abdurachman ${ }^{38)}$ , dengan cara mengatur pola tanam pada budidaya jagung dan ubi kayu, terlebih dahulu ditanami kacang tanah, produksi jagung dapat meningkat $29 \%$, dan produksi ubi $50 \%$. Untuk daerah dataran tinggi, banyak tumbuh tanaman perdu Titonia diversifolia (paitan), tanaman ini telah dikembangkan sebagai sumber bahan organik untukmeningkatkan ketersediaan hara. Penggunaan tanaman ini sebagai pupuk hijau mampu meningkatkan ketersediaan dan serapan $P$ tanaman jagung di Andisol, dan menurunkan konsentrasi Aldd (Utami et al ${ }^{36)}$; Prasetia et al ${ }^{26)}$. Dari hasil penelitian Suntoro, bahwa, penggunaan pupuk kandang dengan dosis 9,5 $\mathrm{t}$ ha- 1 , mampu meningkatkan hasil biji kacang tanah $38,72 \%$ dengan hasil 2,13 t ha-1, dan efek residunya untuk musim tanam berikutnya, mampu memberikan hasil lebih tinggi yaitu sebesar 2,6 $\mathrm{t} / \mathrm{ha}^{33)}$.

Pemberian bahan organik menemui kendala karena harus diberikan dalam jumlah besar, dan ini biasanya susah untuk mendapatkannya, walapun banyak limbah organik sampah pasar atau sampah rumah tangga.

Perubahan kondisi lahan pertanian kearah suboptimal disebabkan karena penggunaan bahan agrokimia berlebihan, sehingga menimbulkan kejenuhan akan cemaran logam berat, cemaran pestisda, dan menurunnnya kapasitas daya dukung karena degradasi bahan organik di dalam tanah. Permasalahan ini tidak saja terjadi di Indonesia, tetapi juga di negara maju. Mengatasi kendala ini banyak penelitian yang telah dilakukan yaitu dengan memanipulasi asam-umik(humic acide) yang mempunyai sifat dan fungsi sama dengan bahan organik atau kompos. Keberhasilan ekstraksi dan isolasi asam-humik dari berbagai jenis bahan organik, memberikan dampak pada caracara pembenahan tanah yang lebih efektif dan efesien ${ }^{23)}$.

Makalah ini memaparkan salah satu kajian secara umum, mengenalkan manfaat dan prospek asam-humat yang sangat potensial, namun ranah ini belum banyak mendapat perhatian bagi para peneliti, khususnya yang berkaitan dengan bidang pertanian. Padahal Indonesia kaya akan sumber ini, dan kita mengalami krisis untuk pemuliaan lahan dalam upaya pemenuhan ketahanan pangan. Diharapkan ulasan dalam makalah ini akan menggugah kompetensi para paneliti, untuk mengembangkan manfaat sumber-sumber asam-humat di Indonesia.

\section{ASAM-HUMAT (Humic-acid)}

Terminologi aslinya dalam bahasa romawi disebutnya "humus", adalah bagian dari bahan organik didalam tanah, dari hasil transformasi proses fisik, kimia, dan biodegradasi (humifikasi) dari biomolekul. Sederhananya batasan humus sejak tahun 1761 yaitu bahan-bahan organik yang mengalami proses dekomposisi secara alamiah dan disebutkan secara umum "humic subtances"34). Berdasarkan karakter kelarutannya pada kondisi kemasaman larutan, dibedakan dua komponen yaitu asam-humat "Humic-acid" dan asam-fulfat "Fulvic-acid". Kedua senyawa ini dialam menjadi satu, dan dapat dipisahkan pada kondisi kemasaman tertentu. Asam humat adalah komponen terpenting dari senyawa humus karena dari hasil penelitian diketahui 
bahwa, membantu menggemburkan tanah, dan membantu transfer nutrien dari tanah kedalam tanaman, serta meningkatkan retensi kandungan air, dan memacu pertumbuhan mikroba di dalam tanah ${ }^{7}$.

Asam humat (humic acide) sudah dikenal beberapa ratus tahun yang lalu, di China kira-kira 300 tahun yang lalu sudah memanfaatkan asam humat untuk berbagai keperluan, terutama dalam kepentingan budidaya pertanian. Masyarakat awam dalam keseharian menyebutnya dengan istilah humus pada hal asam humat merupakan salah satu sub-fraksi komponen dari humus yang warna coklat-hitam, senyawa ini yang mempunyai kontribusi pada kuwalitas fisika dan kimia tanah. Para pakar dibidang kimia tanah mendiskripsikan sebagai kelompok substansi bahan alam yang mempunyai banyak khasiat, karena terbentuknya asam humat ini adalah sebagai hasil dari proses endapan bahan organik alam yang sudah terkonsentrasi, dan berlangsung juatan tahun. Maka dari itu dapat dipahami bahwa,substansi humus merupakan fraksi bahan organik yang sangat stabil ${ }^{35}$. Endapan bahan organik yang terkenal yaitu batuan Leonardite yang mempunyai kandungan asamhumat dan asam-vulvat tinggi, sebagai produk akhir dari proses humifikasi yang diperkirakan telah berlangsung sekitar 70 juta tahun, ditemukan di Amerika Selatan oleh ahli geologi bernama Leonard. Batuan leonardite ini terbentuk dari oksidasi lignit, tetapi asam-humat dapat ditemukan pada berbagai jenis endapan bahan organik seperti gambut, batu bara, seresah organic dari tanaman didanau-danau. Hanya saja asam-humat diseresah organik atau tanah konsentrasi sangat rendah kira hanya $0,2 \%-10 \%$.

Di alam asam-humat umumnya merupakan senyawa karbon komplek, senyawa asam-humat berikatan dengan asam-vulvat (vulvic acids), dan pada setiap material organik rationya berbeda-beda, sebagai contoh pada tabel berikut sebagai gambaran kandungan asam-humat dan asam-vulvat pada berbagai jenis sumber bahan alam organik.

\begin{tabular}{|l|c|}
\hline \multicolumn{1}{|c|}{$\begin{array}{c}\text { Sumber Bahan } \\
\text { Organik }\end{array}$} & $\begin{array}{c}\text { Kandungan Asam- } \\
\text { Humat \& fulvat (\%) }\end{array}$ \\
\hline Leonardite/Humat & $40-85$ \\
\hline Gambut hitam & $10-40$ \\
\hline Gambut & $10-20$ \\
\hline Batubara coklat & $10-30$ \\
\hline Kotorang hewan & $5-15$ \\
\hline Kompost & $2-5$ \\
\hline Tanah & $1-5$ \\
\hline Lumpur & $1-5$ \\
\hline Batubara keras & $0-1$ \\
\hline
\end{tabular}

Sumber: Humintech(R)

Perhatian para pakar kimia-tanah pada asam-humat berawal dari penemuan batuan leonardite dan sifat fisika kimianya kira-kira 50 tahun yang lalu diketahui manfaatnya, terutama dibidang pertanian. Memang beberapa tahun yang lalu masih terjadi kontroversi tetang manfaat asam-humat ini. Namun saat ini dan kemudian penelitian merambah kepada jenis-jenis sumber asam-humat yang lain, ternyata asam-humat dapat dimanfaatkan pada berbagai sektor industri, seperti konstruksi bahan bangunan, pengeboran minyak, pakan ternak, bahkan saat ini banyak penelitian dari fraksi asamfulvat untuk suplemen obat.7)

\subsection{Manfaat Asam Humat}

Kajian ilmiah banyak dilakukan berkaitan dengan kepentingan dibidang pertanian. Secara umum bahwa asamhumat dapat berperan merekondisikan tanah sebagai medium tanam menjadi lebih baik. Asam humat dapat mengikat air di dalam tanah, kemampuan tukar ion yang tinggi (CEC), meningkatkan kesuburan tanah dan pertumbuhan tanaman. Dari hasil kajian ada tiga pengaruh utama manfaat asam humat yaitu; 
a. Manfaat secara fisik pada tanah; Memperbaiki struktur tanah; melindungi kehilangan air dan nutrisi karena sinar matahari terutama pada tanah yang berpasir. Secara bersamaan pula akan mengkonversi nutrisi tersebut dengan jalan dekomposisi tanah menjadi bermanfaat. Pada kondisi tanah yang sangat padat/keras, dapat memperbaiki tingkat aerasi dan rentensi air, sehingga dapat ditanami.

b. Manfaat secara kimia pada tanah; Dapat menetralisir kondisi tanah asam atau alkali, meregulasi nilai $\mathrm{pH}$ tanah. Meningkatkan dan mengoptimalkan asupan nutrisi dan air oleh tanaman. Berlaku sebagai kelator untuk unsur logam pada kondisi tanah alakali, dan membantu asupan kedalam akar tanaman.Membantu konversi elemen dalam nutrisi( N,P.K,Fe,Zn dan unsur mikro lainnya) dalam bentuk yang mudah diserap oleh tanaman. Dan meningkatkan asupan nitrogen oleh tanaman.

c. Manfaat secara biologis bagi tanaman; Menstimulasi dan meningkatkan produksi ensim pada tanaman. Berlaku sebagai biokatalis pada proses biologi. Menstimulasi pertumbuhan akar, terutama pada akar tunggang/vertical, sehingga lebih memberikan kesempatan untuk asupan nutrisi yang lebih baik. Meningkatkan kandungan vitamin dan mineral pada tanaman. Menstimulasi pertumbuhan tanaman, dengan cara mempercepat pembelahan sel, meningkatkan percepatan pertumbuhan system perakaran dan hasil panen berat kering.

Didalam tanaman Asam humat dan fulvat dapat meningkatkan kadungan klorofil pada daun, dan mempercepat metabolisme energi didalam sel. Meningkatkan produksi senyawa Adenosine Triphosphate (ATP) didalam sel. Berbagai system rekasi metabolisme yang diaktivasi oleh substansi asam humat akan terjadi peningkatan produksi ikatan senyawa ATP. Senyawa ATP sebagai energi metabolite yang berfungsi mengendalikan berbagai reaksi metabolisme.

\subsection{Karakteristik Struktur Kimia}

Fenomena yang fantastik asam humat pada tanaman, menggugah lebih dalam keingintahuan para ahli kimia, terutama pada teknik-teknik isolasi dan karakter komponen fraksi dari substansi humus, serta sifat senyawa tidak saja asam-humat juga pada asam fulvat. Sejak ahir abad ke-18 substansi humus masih digambarkan dalam struktur asam humat, asam vulvat dan humat. Ketiga fraksi ini dibedakan hanya berdasarkan sifat kelarutan pada kondisi asam dan alkali, yang hanya menggambarkan dari sisi perlakuan bahan saja, hal ini tidak memberikan informasi analisis kimianya dari bahan ektraksi ${ }^{30}$. Substansi humus dapat dipilahkan kedalam tiga fraksi besar yaitu;1) Humat, Asam-humat, dan Asam-vulvat. Dari pendekatan yang sederhana sifat kimia bahan organik ini, Pettit,E.R ${ }^{22}$, menjelaskan beberapa karakter kimia dari komponen senyawa substansi humus yaitu;

a. Asam-humat (humic acids), adalah fraksi dari substansi humin, yang tidak larut didalam air pada $\mathrm{Ph}$ rendah $(\mathrm{Ph}<2)$, tetapi larut pada nilai $\mathrm{Ph}$ tinggi, biasanya mayoritas hasil ektraksi dari humin, berwarna coklat-hitam. Struktur tersusun dari rantai karbon alipatik dan ikatan senyawa aromatic. Ratarata terdapat $35 \%$ adalah senyawa aromatic, dan sisanya adlah senyawa alipatik. Mempunyai berat molekul 10.000-100.000 D.Asam-humat umumnya tersedia dalam bentuk garam dengan elemen unsure mikro. Dari hasil analisa menunjukkan bahwa didalam molekul asam-humat dapat ditemukan lebih dari 60 jenis elemen mineral yang berbeda. Unsur mineral ini terikat 
dalam struktur molekul yang siap untuk dapat dimanfaatkan oleh berbagai jenis organisme hidup. Dari struktur susunan molekul yang demikian memberikan fungsi penting dalam system sebagai penukar ion dan khelator.

b. Asam fulvat(fulvic acids), adalah fraksi dari substansi humin, larut didalam air pada segala kondisi nilai pH asam, netral dan alkali, ini biasanya didapatkan sebagai sisa hasil ektraksi asam-humat, berwarna kuning-coklat. Asam fulvat mempunyai ukuran yang lebih kecil dari asam-humat, dengan rentang berat molekul 1000-10.000
Dalton. Asam fulvat mempunyai kandungan oksigen 2 kali ganda dari asam-humat; mempunyai banyak gusus dari golongan karboksil(COOH) dan hidroksil(COH) dan umumnya secara kimiawi sifatnya lebih rekatif; kapasitas tukar ion(CEC) dua kali ganda. Banyaknya gugus karboksil ini memberikan kemapuan tukar ion tinggi pula. Jumlah gugus karboksil pada asam vulvat antara $520-1120 \mathrm{cmol}(\mathrm{H}+) /$ $\mathrm{Kg}$. Dari hasil analisa kebanyakan asamvulvat tidak ada gugus metoksi(CH3), senyawa penol rendah, ikatan senyawa aromatic lebih sedikit dibandingkan dengan asam-humat.

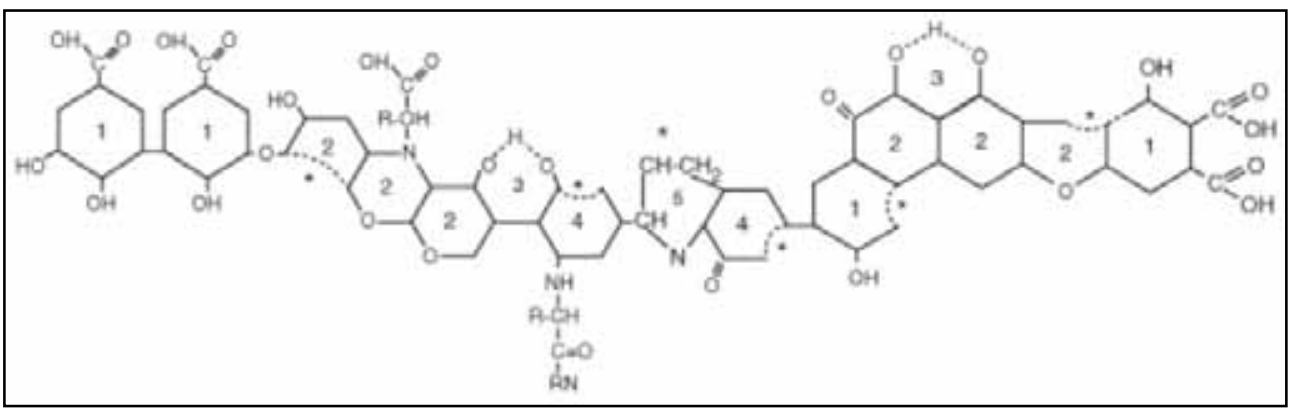

Struktur molekul asam humat (humic acide) teroksidasi. Struktur organik asam humat yang secara alamiah teroksidasi, (diperlihatkan dengan adanya asterisks), memberikan muatan negative. Ion positif secara atraktif memutuskan rantai pada tapak oksidasi, yang akan berfungsi untuk menempel mikronutrien dan mikroflora.<smiles>CC(CC(=O)O)C(CO)C(=O)Cc1c(CCC(=O)C(=O)O)c(O)c2c(C(=O)O)c(C(=O)O)c(C(=O)O)c(O)c2c1C(=O)O</smiles> 
Karena ukuran molekul asam-fulvat relative kecil, ini yang sangat memungkinkan mudah terserap atau masuk, kedalam bagian akar, batang, dan daun dari tanaman, dan dapat bertindak sebagai pembawa unsurunsur mikro dari permukaan akar tanaman masuk kedalam jaringan. Fenomena inilah yang memberikan efektifitas asam-humat, khususnya adanya asam-fulvat dapat digunakan sebagai activator pemupukan melalui daun.

Piccollo ${ }^{23)}$, mengembangkan teknik baru yaitu, dengan teknik fraksinasi sequensial, substansi humus, yang mengandung campuran hasil transformasi bahan biomolekul yang menunjukkan struktur supramolekuler dapat dipisah-pisahkan menjadi komponen molekul yang lebih kecil, dan ini memberikan harapan untuk mengoptimalkan manfaat dari substansi humus.

Model hipotesis struktur molekul asamfulfat (Buffel model), terdiri dari struktur aliphatic dan aromatic, keduanya sangat extensive tersubstitusi dengan kelompok oksigen dan gugus yang fungsional. Karena molekul yang relatif kecil asam-fulvat jika terlepas didalam tanah siap masuk kedalam sistem akar tanaman, batang, dan daun sebagai pembawa unsur mikro dari permukaan tanaman masuk kedalam jaringan.

\section{ASAM HUMAT PEMBENAH TANAH}

Sifat fisika dan kima asam-humat didalam tanah yang penting hubungannya dengan memperbaiki sifat fisik,kimia dan biologi tanah yaitu;1). Fraksi humat dapat meningkatkan nilai KTK, dan stabilisasi struktur tanah ${ }^{24)}, 2$ ). Fraksi humat dapat mengurangi pengunaan pupuk $\mathrm{N}$ dan $\mathrm{P}$ (Day et $a^{(6)}$; Falatfah et $a^{8)}$. Sifat ini karena fraksi humat mampu meningkatkan kemampuan tanah dalam mengikat, menyerap, dan mempertukarkan kation, serta membentuk senyawa komplek dengan logam berat dan tanah lempung, 3).Fraksi humat dilaporkan oleh Thorn ${ }^{36)}$, Kelly dan Stevenson ${ }^{15)}$, mempunyai arti penting untuk penyuburan tanah dan stabilisasi kandungan nitrogen. Meningkatkan kapasitas pengikatan air pada tanah, sehingga dapat mengurangi penggunaan air ${ }^{27)}$, dan 4). Fraksi humat dapat menyediakan unsur hara seperti $\mathrm{N}, \mathrm{P}, \mathrm{K}, \mathrm{S}$ dan $\mathrm{Zn}$ ke dalam tanah serta $\mathrm{C}$ sebagai sumber makanan bagi mikroba $\operatorname{tanah}^{9}$.

Manfaat senyawa humat pada rehabilitasi kondisi fisik, kimia, dan biologi tanah, kasap mata telah dibuktikan oleh para peneliti bahwa, senyawa humat tidak saja merekondisikan tektur tanah, tetapi juga sangat bermanfaat untuk menjerap polutan logam berat, senyawa organik persisten seperti herbisida, insektisida, nematisida, dioxins dan beberapa senyawa farmasi estrogenik didalam tanah dan air ${ }^{31,17)}$. Kompleksitas alamiah ineteraksi antara senyawa asam-humat dan xenobiotics serta pengaruhnya terhadap kualitas lingkungan (air, tanah, atmosfer) dari proses industri, penelitian telah dilakukan oleh Pacheco et al ${ }^{21)}$, dikatakan bahwa beberapa polutan senyawa organik/anorganik hanya dapat diikat oleh asam-humat,menjadi komponen bentuk supramolekul yang stabil. Menurut Wandruska.R.V ${ }^{40)}$, asam humat dapat berfungsi sebagai detergent untuk menghilangkan kandungan cemaran logam berat substansi cairan. Sebagai contoh potensi asam-humat untuk remediasi air diteliti oleh Seied et.al ${ }^{26)} ., 2005$ ), efektif membentuk senyawa khelat dengan logam berat seperti $\mathrm{Pb}, \mathrm{Cu}, \mathrm{Fe}, \mathrm{Zn}, \mathrm{Ni}, \mathrm{Cr}$, afinitasnya sangat tergantung pula dengan kondisi $\mathrm{pH}$ air, namun demikian umumnya pada kisaran pH.6-pH.7 afinitasnya sangat kuat. Penelitian yang dilakukan oleh Lesnikova.E et.al ${ }^{27)}$, dengan menggunakan absorben berbasis asam-humat dapat untuk memurnikan air dari berbagai jenis logam berat seperti (Cu, Zn,Ni,Pb,Fe,Co,Hg,Mo,W, $\mathrm{Cr}, \mathrm{Al}, \mathrm{As}, \mathrm{U}$, dlI). Peneliti lain mempelajari pengaruh pemberian asam-humat dan asam sitrat pada budidaya kacang hijau, dapat menurunkan kandungan atau toksisitas 
logam Almunium(Al) pada pada tanaman kacang hijau ${ }^{3}$. Pembenahan tanah dari cemaran herbisida jenis glyphosate, $\mathrm{N}$-(phosphonomethyl) glycine diteliti oleh Picolo.A et $\mathrm{al}^{25)}$, dikatakan bahwa asamhumat cukup efektif untuk mengikat gugus aktifnya, dan pada aplikasinya karena herbisida dapat terjerap tidak hanya pada permukaan tanah, akan lebih efektif jika digunakan asam-humat yang larut di dalam air.

Pengaruh dan manfaat asam-humat sebagai pembenahan tanah pengkayaan kandungan karbon(C), fraksi asam-fulvat dapat memperkaya 5-9\% kandungan C dalam tanah, dan fraksi asam-humat lebih besar sekitar $16 \%$, dan senyawa humat $8 \%{ }^{37)}$. Dikatakan lebih jauh bahwa fenomena pengkayaan ini masih tergantung pada fraksi substansi humat, serta kondisi musim. Aplikasi secara individual tiap fraksi akan menunjukkan efektifitas yang berbedabeda. Efesiensi penggunaan pupuk $(\mathrm{N})$ pada budidaya tebu sebagai upaya menurunkan kejenuhan tanah terhadap pupuk diteliti oleh Nuryani dkk, ${ }^{20)}$, dikemukakan bahwa dengan pengikatan urea dalam asam-humat, dapat meningkatkan efesiensi pengurangan konsumsi pupuk-N sampai $50 \%$. Hasil penelitian menunjukkan, penambahan bahan humat $1 \%$ pada tanah jenis latosol mampu meningkatkan $35,75 \%$ pori air tersedia, dari $6,07 \%$ menjadi $8,24 \%$ volume $^{12)}$.

Fungsi asam-humat sebagai pembenah tanah, berpengaruh juga terhadap budidaya usaha tani. Sebagai contoh penelitian yang dilakukan oleh produsen asam-humat di Jerman

Dari beberapa contoh diatas memberikan informasi yang cukup bermakna bahwa, asam-humat (humic-acide), dapat berperanan multi fungsi tidak saja untuk pembenahan tanah, tetapi juga pembnahan sumber air, dari dampak cemaran bahanbahan agrokimia ataupun limbah industri yang berdampak pada resiko kesehatan manusia.

Dalam usaha pertanian tanah mempunyai fungsi utama sebagai sumber penggunaan unsur hara yang dibutuhkan untuk pertumbuhan tanaman, dan sebagai tempat tumbuh dan berpegangnya akar serta tempat penyimpan air yang sangat diperlukan untuk kelangsungan hidup tumbuhan ${ }^{33)}$. Tanah sebagai sumberdaya alam yang dapat dimanfaatkan oleh manusia untuk berbagai macam aktivitas guna memenuhi kebutuhan hidupnya. Tanah sebagai sumberdaya yang digunakan untuk keperluan pertanian dapat bersifat sebagai sumberdaya yang dapat pulih (reversible) dan dapat pula sebagai sumberdaya yang dapat habis ${ }^{29}$. Bertolak dari fenomena diatas, perlu adanya tolak pikir ulang bagaimana tanah yang sudah ada harus diselamatkan dari kepunahan manfaatnya untuk memenuhi kebutuhan pangan.

Catatan dari Deperatemen Pertanian pada tahun 1992, kurang lebih 18 juta ha lahan di Indonesia telah mengalami degradasi yang meliputi 7,5 juta hektar lahan potensial kritis, 6 juta hektar lahan semi kritis, dan 4,9 juta hektar lahan kritis. Sedangkan Badan Pusat Statistik laporannya pada tahun 2002 mencatat luas lahan yang terdegradasi mencapai 38,6 juta hektar ${ }^{13)}$. Sementara itu Departemen Kehuatanan dan Perkebunan dari laporannya(2002), mencacat inventarisasi lahan kritis pada lahan budi daya pertanian mencapai 21.944.595,7 hektar, dengan katagori sangat kritis 223.607,00 hektar, kritis 1.246.515,13 hektar, agak kritis 1.892.907,29 hektar, dan potensial kritis mencapai 4.712.485,51 hektar. Kondisi di Pulau Jawa dikemukakan oleh Upik Rosliana luasan lahan kritis di Jawa sudah mencapai 900.000 hektar(Warta Bumi,16 April., 2010).

Informasi data diatas walaupun berbeda-beda dari para pihak sumber, yang perlu dipahami bahwa saat ini telah terjadi bencana pada lahan-lahan produksi pangan di Indonesia yang memerlukan pemualiaan atau rehabilitas segera. Upaya pemuliaan ini tidak mudah,karena memerlukan proses waktu, dan biaya yang mahal. Dengan demikian perlu diupayakan kiat-kiat metoda 
yang murah, efektif dan efesien.

Dikemukakan oleh Mathyew.L bahwa, pemanfaatan substansi asam-humat pada lahan pertanian sudah cukup mapan di dunia ${ }^{18)}$, khusunya pada tanah-tanah yang rendah kandungan bahan organiknya ${ }^{4)}$. Langkah penerapan asam-humat untuk pembenah tanah merupakan satu bagian integral dari kesatuan ekosistem dan mempunyai peranan penting di dalam siklus global nutrient dan carbon ${ }^{18)}$.

\section{KESIMPULAN}

Substansi asam-humat menyediakan bahan-organik dalam bentuk yang ekonomis dan terkonsentrat, dapat menggantikan humus yang hilang, akibat dari penggunaan pupuk konvensional ${ }^{2)}$. Penelitian yang dilakukan oleh Chen, et $\mathrm{al}^{5}$, bahwa dengan penambahan asam-umat ke tanah termasuk tanah pasir, dapat menstimulasi pertumbuhan yang lebih baik, dari pada jika hanya diberikan mineral atau nutrisi saja.

Paparan diatas bahasan tentang substansi asam-humat memberikan gambaran bahwa introduksi asam-humat dapat menjadi salah satu solusi untuk pembenahan tanah kritis yang yang efektif karena mempunyai kemampuan untuk;

1. Membentuk senyawa khelat-nutrient

2. Meningkatkan/memperbaiki pasokan khususnya unsur fosfor, sulfur dan nitrogen

3. Menjerap senyawa toksin dari dalam tanah

4. Menstimulasi aktifitas mirkoba dalam tanah

5. Memfasilitasi kelarutan mineral

6. Berperanan sebagai penyimpan unsur $\mathrm{N}, \mathrm{P}, \mathrm{S}$, dan Zn.

7. Memperbaiki kapasitas tanah mengikat air

Di Indonesia, walaupun masih ada kontroversi diantara para pakar dibidang agronomi dan pakar ilmu tanah untuk penerapan asam-humat sebagai pembenah tanah, namun contoh-contoh di atas perlu untuk dicermati dan dilakukan kajian. Sumber asam-humat cukup banyak di Indoneia seperti, batu bara, tanah gambut, dan endapan humus, luasan tanah kritis cukup memprihatinkan dan membutuhkan penangan segera dengan metode yang efektif, dan efesien.

\section{DAFTAR PUSTAKA}

1. Ardiwinata,A.N.,S.Y Jatmiko, and E.S Harsanti., 1999. Monitoring Residu Insektisida di Jawa Barat. Risalah Seminar. Hasil Penelitian Emisi GRK dan Peningkatan Produksi Padi di Lahan sawah Menuju Sistem Produksi Padi Berwawasan Lingkungan. Puslitbangtan, Bogor.

2. Burdick,E.M.,1965. Comercial Humats for Agriculture and the Fertilizer Industri. Economic Botany. Vol.19,No.2:152-156.

3. Badora.A ., F. Tadeuz., Citric Acide and Humic Acifd for the Decrease of Al Toxicity for Common Pea (Pisum sativum L). Presentation poster. Dep. Of Agricullture Chemistry, Agricultural University of Lubin. Polandia.

4. Chen, Y and Aviad.T.,1990. Effects of Humic Substances on Plant Growth. In MacCarthy,C.E. Clapp.R.L.Malcolm, and P.R.Bloom (eds), Humic Substances in Soil and Crops Sciences: Selected Readings. Soil.Sci Society of America. pp.161-186.

5. Chen.Y.,Clapp.C.E.,Magen.H., 2001. Plant Growth Stimulation by Humic Substances and Their Complexes wit Iron. Procs. Int.Ferilizer Soc. Symposium. Lisbon,March 2001.

6. Day,K.S.,Thornton,R.and Kreeft.H.,2000. Humic Acid Products for Improved Phosphorus Frtilizer Mangement. In Humic Susbtances, Versatile Componen of Plant, Soil and Water, E.A. Gahabour, (ed). Royal Society of Chemistry,pp.321-325. 
7. Elaida.M.,Mendez,P. Havel.J. Patocka.J.,(2006). Humic Substances wich Element Still Unknow Structure: Product's Application in Agricukture \& Industry. J.Appl.Biomed.3: 15-24.

8. Falatfah,A.K.,2001. A Comparative Evaluation of Known Liquid Humic Acid Analysis Methods. In E.A Ghabbour and Davies(eds). Humic Substances: Structure, Models and Functions. Royal Society of Chemystry.Cambridge. UK. pp.337-342

9. Frank,K.D., and Roeth,F.W. 1996. Using Soil Organic Mater to Help Make Fertilizer and Pesticide Recommendation. In: Soil Organic Mater, Analysis and Interpretation. Soil Science Society of America. Special Publication No.46,p,33.

10. Hakim.N., 1985. Pengaruh Sisa Pupuk Hijau,Kapur,Pupuk P dan Mg pada tanah podsolik terhadap Produksi Jagung. Makalah Seminar Hasil Penelitian Perguruan Tinggi. Bandung, 25-28 Feb. DitJen.Dikti.Depdikbud.

11. Handayanto, E. 1999. Komponen biologi tanah sebagai bioindikator kesehatan dan produktivitas tanah. Universitas Brawijaya. Malang.

12. Herudjito, D. 1999 Pengaruh bahan humat dari air gambut terhadap sifstsifst tanah latosol (Oxic Dystropepts). Konggres Nasional VII . HITI. Bandung.

13. Irsal.L., K.Subagyono., dan A.P Setiyanto.,2006. Isu dan Pengelolaan Lingkungan Dalam Revitalisasi Pertanian. J.Litbang Pertanian (25).3: 106-114.

14. Kasno,A.,Suwandi., dan I.Anas.,2003. Usaha Mengurangi Kadar Logam Berat Melalui Pengapuran pada tanah tercemar tailing. Proc. Seminar Nasional Pengelolaan Lingkungan Pertanian. Pusat Pen.\& Peng.Agroklimat.Bogor.

15. Kelly,K.R., and Stevenson,F.J., 1996. Organic froms of $\mathrm{N}$ in Soil. In: Humic Substances in Terestrial Ecosystem. Edited by A.Piccolo.pp.407-427.

16. Lesinkova.E., Nadezhda.A.,
Valentina.L.,2008. Technolgy of Waste Waters Purification Using Natural Sorbents Based on Humic Material Derived from Brown Coals. Proc. Int. Meeting of The International Humic Substances Society. September 14-19. Sain Petersburg. Moscow.Rusia.

17. Loffredo.E.,M.Pezzuto.,N.Sensei.,2000. Humic Substances: Versatile Componen of Plant,Soil,Water. E.A. Ghabbour and Davies (eds):RSC, Cambridge.

18. MacCarthy,P.,2003. Humic Substances: What We Know and Whot We Don' Know. Symposium on Natural Organic Mater in Soil \& Waters. Iowa State University,Ames, lowa. March 22.

19. Mahfudz.,2001. Peningkatan Produktivitas Lahan Kritis Untuk Pemenuhan Pangan Melalui Usahatani Konservasi. Makalah Falsafah Sains (PPs 702). Program Pasca Sarjana/S3. Institut Pertanian Bogor.

20. Nuryani.S,H.U., Purwanto.B,H., Mass.A., Wiwik,E.W., Oka,A.B.,K.D. Sasmita.,2007. Peningkatan Efesiensi Pemupukan (N) Pada Tanaman Tebu Melalui Rekayasa Khelat Urea-Humat. J. Ilmu Tanah \& Lingkungan. Vol.7 No.2: 93-102.

21. Pacheco,M.I.,E.M, Pefia-Mendez., J. Havel.,2003. Supramolecular interaction of Humic Acid With Organic and Anorganic xenobiotics Studied by Capilary Electroporesis. Chemosphere 51:95-108.

22.Pettit, Dr. Robert E.,1997. Emeritus Associate Professor TEXAS A \& M UNIVERSITY,Organic Matter, Humus, Humates, Humic Acid, Fulvic Acid and Humin: Their Importance in Soil Fertility and Plant Health. CTI Research.

23. Picocolo.A. 2002. The Supramolecular structure oh humic acide substances. Novel understanding of humus chemistry and implication. Advances in Agronomy,75:57-134.

24. Picolo.A., and Mbagwu,H.S.C.,1999. Role of Hydrophobic Component of Soil 
Organic Mater in Soil Aggregate Stability. J. Soil Science Society od America. 63:1808-1810.

25. Picolo.A., Celano.G.,Conte.P.,1966. Adsorption of Glyophosate by Humic Substances. J.Agric.Food Chem. 44. 2442-2448.

26. Prasetya. B., Hairiah, K. dan Dewi, C.S. 2002. Kontribusi biomasa Tithonia diversifola (paitan) dan inokulasi Vesikular Arbuskular Mikoriza (VAM) terhadap ketersediaan dan serapan $\mathrm{P}$ tanaman jagung pada andisol. Seminar Nasional IV. Pengembangan Wilayah Lahan Kering. Mataram.

27. Russo,R.O and Berlyn,G.P.,1990. The Use of Organic Biostimulants to Help Low Input Sustainable Agriculture. J.Sustainable Agriculture. Vol.1(2):19-42.

28. Saied.S.,A.Siddique.,M.Mumtaz., and K.Ali.,2005. Studi of The Heavy Metal Pollution Treatment. Potential of The Coal Generated Humic Acid. J. Basic \& Appl.Sci. Vol.1.No.2.Pakistan.

29. Santoso, P. and Ahmad Safrudin, 1991. Dampak Pembangunan Terhadap Tanah, Tataguna Lahan dan Tata ruang. Konggres Nasional VI . HITI. Bandung.

30. Schnitzer, 1999., Forward. In: Ghabbour, E.A and Davis, G(eds), Understanding Humic Substances: Edvans Methodes, Propertis and Application. Royal Society Chemistry, Cambride,UK.p.vii.).

31. Shin.D., Y.Chung., Y.Choi., 1999. Assessment of Disinfection by-product in Drinking Water in Korea. J.Expo.Anal. Environ.Epidemiol. 9:192-199.

32. Sugito,Y.,Nuraini,Y. dan Nihayati,E.,1995.
Sistem Pertanian Organik. Faperta Unibraw. Malang.

33. Suntoro.,2003. Peranan Bahan Organik Terhadap Kesuburan Tanah dan Pengelolaannya. Orasi Guru Besar. Universitas Sebelas Maret. Januari.2003.

34. Stevenson,F.J.,1982. Humus Chemistry. $2^{\text {nd }}$. ed. John Wiley \& Son. New York

35. Stevenson,F.J.,1994. Humus Chemistry, Genesis, Compocition, Reaction, $2^{\text {nd }} . e d$ John Wilay \& Sons., New York.

36. Thorn,K.A and M,K.Mikita.,2000. Nitrite Fixation by Humic Substances. J. Soil Science Society of America. 64:568-582.

37. Thymothy.A.D.,O.C,Devere.,W.R.Ho warth.,2003. Short-term Soil Carbon Dynamic of Humic Fractions in LowInput and Organic Cropping System. Geoderma 114:319-331. Elsevier.

38. Toha,H.M dan Abdurrahman.A.,1991. Penggunaan Bahan Organik pada Pola Tanam lahan Kering di Tanah Vulkanik eutropept Labolatorium Lapngan Ungaran, Semarang. Laporan Proyek. Badan Penelitian \& Pengembangan Pertanian. Dep.Pertanian.

39. Utami, S.R., Hariah, K dan Supriyadi, 2002. Pemanfaatan bahan organik insitu (Tithonia diversifola dan Tephrosia candida): meningkatkan ketersediaan fosfor pada andisol. Seminar Nasional IV. Pengembangan Wilayah Lahan Kering. Mataram.

40. Wandruszka.R. von.,2000. Humic Acide: Their Detergent Qualities and Potential Uses in Pollution Remediation. J.Royal Society of.Chem.Geochem. Amer. Chem.Soc.2:pp-6. 